DOI: $10.2478 /$ auseb-2014-0010

\title{
Changes in Education Funding in Hungary
}

\author{
Attila MADARAS \\ Kaposvár University, \\ Szent Benedek High School and Vocational Training School \\ József VARGA \\ Corvinus University \\ Kaposvár University
}

\begin{abstract}
Our study examines some of the key aspects of education funding in Hungary. The theme of this publication is a current issue because the financing of Hungarian education has been dramatically changed from October 2013 on. Enrolment-based funding has been replaced by the average salary-based normative support, and the new "teacher career model" has been introduced. The study demonstrates the changes in financing using a model school, the calculations being based on the Budget Act of each year. We look at the trends of the previous system of financing, analysing the data from 2003 to 2012. We can compare the new, average salary-based funding with the normative support in 2012. By comparing the two types of funding, we attempt to find out whether the changes in Hungarian public education represent an opportunity for true transformation or they will remain a mere alteration in the calculation method of funding.
\end{abstract}

Keywords and phrases: public education, human capital, normative per capita contribution, teacher career mode

JEL Classification: I2, H5

\section{Introduction}

The role of human capital is more and more recognized worldwide. Human capital is considered to be one of the key motors of economic development. Adequately trained workforce is needed in the labour market as well as in the society as a whole. Education plays a key role in the improvement of human capital. For this reason, it can be observed, especially in more developed countries, that governments dedicate more and more of their funds to this strategic area. The importance of human capital - the fact that a person's knowledge has economic value - was recognized by early economic science. 
Here are some examples of the concept of human capital being considered in early economic science:

In the $17^{\text {th }}$ Century, William Petty used and attempted to define the expression "human capital" and considered it to be a component of national wealth. He estimated the value of human capital to be 80 pound sterling per capita (Varga, 1998).

Adam Smith (1723-1790) did not only consider machinery and tools to be investments that would pay off and produce profits, but he also considered the training of workers as the same kind of valuable investment. The investor can expect similar payoff and profits from his expenditures on the training of workers as from his investment on machinery. He considered the economically useful knowledge and skills of each member of society - that is, human capital - to be a part of the fixed capital (Smith, 1992).

T. R. Malthaus (1766-1834) pointed out that education can elevate lower class citizens of society into the middle class. He asserts that education for life, as part of schooling, has no additional costs; so, funding it is the government's duty. He was an advocate of the introduction of compulsory public education in order to eliminate child labour (Malthaus, 1902).

In the first half of the $19^{\text {th }}$ Century, J. H. Von Thünen (1783-1850) asserted that educated nations produced more income than less educated ones, using the same material resources. "More educated nations own more capital, the benefit of which is expressed in higher levels of productivity." (Varga, 1998, p.11.)

The recognition of the value of human capital developed alongside the formation of the public education system. The early form of public education appeared in Europe in the $18^{\text {th }}$ century. In Hungary, Queen Marie Theresa's Ratio Educationis (1777) was the first comprehensive legislation regarding public education. Compulsory education was only introduced in 1868 by József Eötvös's XXXVIII/1868 Act on public school education. Children from age 6 to age 12 (15) were mandated to attend school. Compulsory education and the formation of the school system, ranging from elementary schools to universities, inherently improve the qualification of employees.

By the middle of the $20^{\text {th }}$ century, the concept of human capital had come to the front, asserting that by training individuals make an investment in their own productivity. Similarly to any other investment, education also produces yield (Stiglitz, 2000).

The development of human resources is the basis for modernization. It enables individuals to take part in production and political life, to become active citizens of a democratic system. The development of human capital is a long-term process: beginning with public education, continuing with higher education and trainings, to lifelong learning and self-education. "It is quite obvious that the improvement of healthcare, provisioning and education could be the reason and result of economic growth.” (Harbison \& Myers, 1966, p 22.) 
T. W. Schultz (1902-1998), who analysed the relationship between investment in human capital, the production of physical capital and income, received Nobel Prize for his scientific work. He came to the conclusion that human knowledge plays a key role in the economic value of workforce. Producing knowledge is a lengthy and costly process, most similar to the investment processes regarding physical capital. He also points out that human capital is not considered significant within the total capital - although when human skills do not keep up with the development of physical capital, they may become an obstacle to economic growth (Schultz, 1983).

From the second half of the 1970s, due to the economic recession and the budget deficit following the oil crisis, the issue of system efficiency and education funding was raised. Analysing the cost-efficiency of education means examining the level of expenditures needed to accomplish the desired educational goals. Measuring the expenditures is a simple task because the costs per capita and the expenditures can be calculated based on statistics and budget reports. Measuring the efficiency of education, however, is a much greater challenge (Polónyi, 2002).

From 1 October 2013, the Hungarian system of education funding has been changed. The reason for this change was the introduction of the "teacher career model" as a new element in public education as well as the alterations in laws and legislations.

National and international almanacs only list the total amount of public education funding. This, however, not only contains the funds dedicated directly to schools, but also the expenditures on professional pedagogical services, coaching programmes for struggling learners, professional development programmes, one-time investments etc.

To demonstrate the changes in financing, we model a school. First, we are going to look at the yearly amounts of government support from 2003 to 2012; then we are going to compare the government funding in 2012 with the funding after the introduction of the new "teacher career model" in 2013, assuming the number of students to be constant. The number of full-time students will be 480, each class having 30 students. The school levels will be the following: elementary and middle school (grades 1-8), high school (grades 9-12), vocational training school (grades 1/11-2/12) and vocational secondary school (grades 1/13-2/14) - each grade having one class, totalling 16 classes in the school. This model will be used to demonstrate the financing of public education. In Chapter 2, we are going to look at the financing of public education based on the funding from the central budget and the additional per-capita grant for church schools. The latter amount equals the average funding provided by local governments. At the end of the chapter, we are going to look at the level of total funding. 


\section{Education Funding from 2003 to 2012}

\section{Normative Per-Capita Basic Contribution 2003-2012}

The normative per-capita basic contribution is granted by the state to every school proprietor based on the enrolment numbers. This grant represents the most significant budget line within the public education budget. The mode of financing has changed several times in the last 8 years. The grant was sometimes based on the calendar year and sometimes on the school year. To simplify the model and make it more transparent, changes are always taken into consideration as of January 1. The logic of our calculations is different from the build-up of the national budget. The National Budget Law lists the funding of vocational theoretical training under the per-capita basic contributions, but the funding of vocational practical training is listed under "additional normative per-capita contributions." However, for practical training within the school, learning in training workshops and training offices - usually takes place in the school building and classes are part of the daily schedule. Thus, we are going to list these funds as part of the basic contribution.

For each year, the amount of government support for the model school is determined according to areas of entitlement, based on the Annual Budget Act.

Table 1. The nominal values of the per-capita basic contribution from 2003 to 2012 (thousand HUF)

\begin{tabular}{lccc}
\hline & $\begin{array}{c}\text { Amount of basic } \\
\text { contribution }\end{array}$ & $\begin{array}{c}\text { Change compared to } \\
\text { base value (2003) }\end{array}$ & $\begin{array}{c}\text { Change compared to } \\
\text { previous year }\end{array}$ \\
\hline 2003 & 109,56 & $100 \%$ & $100 \%$ \\
\hline 2004 & 113,52 & $104 \%$ & $104 \%$ \\
\hline 2005 & 120 & $110 \%$ & $106 \%$ \\
\hline 2006 & 120 & $110 \%$ & $100 \%$ \\
\hline 2007 & 112,487 & $103 \%$ & $94 \%$ \\
\hline 2009 & 109,252 & $100 \%$ & $97 \%$ \\
\hline 2010 & 105,662 & $96 \%$ & $97 \%$ \\
\hline 2011 & 96,442 & $88 \%$ & $91 \%$ \\
\hline 2012 & 96,442 & $88 \%$ & $100 \%$ \\
\hline
\end{tabular}

Source: own calculations based on the Annual Budget Act of each year

The amounts in Table 1 are nominal values. It can be clearly seen that the government support increases at the beginning, but persistently declines from 2006. In 2007, a crisis hit Hungary, and the government announced an educational reform. Looking back, we can now see that the reform primarily consisted of a decrease in funding, with only minor changes in structure and pedagogy. The 
government support for school proprietors from the central budget has been on a steady decline in the second half of the decade. The effects of the world economic crisis can be most clearly felt from January 2010 on, with the decrease being more than $10 \%$. It is a major concern how school proprietors can make up for the decline of government funding from their own resources in a crisis economy. In 2011 and 2012, the basic contributions remain the same as in 2010.

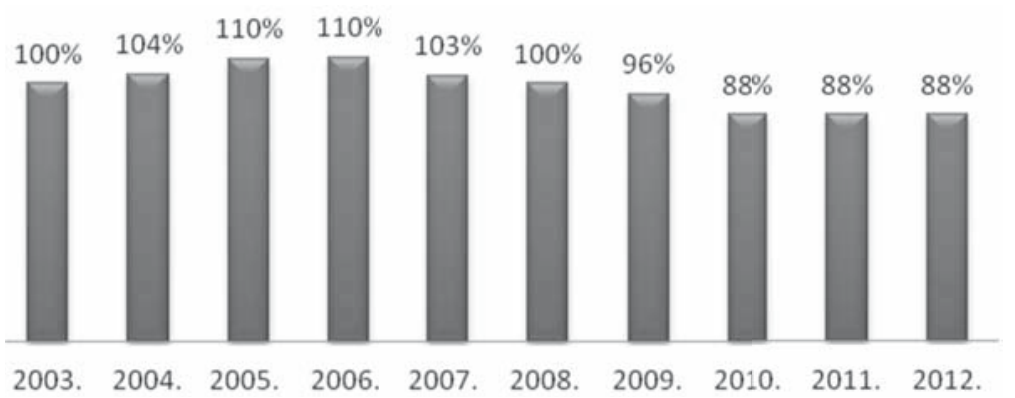

Source: own calculations

Figure 1. Normative per-capita basic contribution, changes in nominal values, 2003-2012 (\%)

So far, we have looked at the nominal values of government funding, which are visualized in Figure 1. It is worthwhile to examine the trends of government support taking into account the changes of the consumer price index in Hungary in the past 8 years.

Table 2. Real values of normative per -capita basic contribution 2003-2012 (thousand HUF)

\begin{tabular}{ccccc}
\hline Desirable support & $\begin{array}{c}\text { Consumer price } \\
\text { index }\end{array}$ & $\begin{array}{c}\text { Amount of } \\
\text { normative per- } \\
\text { capita basic } \\
\text { contribution }\end{array}$ & $\begin{array}{c}\text { Normative/ } \\
\text { Desirable }\end{array}$ \\
\hline 2003 & 109,56 & $\mathbf{1 0 4 . 7} \%$ & 109,56 & $100 \%$ \\
\hline 2004 & 114,709 & $\mathbf{1 0 6 . 8} \%$ & 113,52 & $99 \%$ \\
\hline 2005 & 122,51 & $\mathbf{1 0 3 . 6} \%$ & 120 & $98 \%$ \\
\hline 2006 & 126,92 & $\mathbf{1 0 3 . 9} \%$ & 120 & $95 \%$ \\
\hline 2007 & 131,87 & $\mathbf{1 0 8 . 0} \%$ & 112,487 & $85 \%$ \\
\hline 2008 & 142,419 & $\mathbf{1 0 6 . 1} \%$ & 109,252 & $77 \%$ \\
\hline 2009 & 151,107 & $\mathbf{1 0 4 . 2} \%$ & 105,662 & $70 \%$ \\
\hline 2011 & 157,453 & $\mathbf{1 0 4 . 9} \%$ & 96,442 & $61 \%$ \\
\hline 2012 & 165,169 & $\mathbf{1 0 3 . 9} \%$ & 96,442 & $58 \%$ \\
\hline
\end{tabular}

*Source: Hungarian National Bank 
The amounts of normative basic contribution are the same as in Table 1. By adjusting those with the consumer price index, we get the amount the government would have needed to provide from the central budget to keep the funding at the 2003 level. These real values of financing appear in the "desirable support" row.

It is interesting to compare Table 1 and Table 2. Looking at the nominal values, government support seems to increase until 2005, stagnate in 2006, and then decrease. Looking at the real values, however, we can see a decline from the beginning. A drastic decrease was brought about by the "educational reform" in 2007 , but the 2010 amount also shows that the government is less and less able to support education during the times of the economic crisis. The funding in 2011 and 2012 is the same as in 2010, but that means a decrease in the real value.

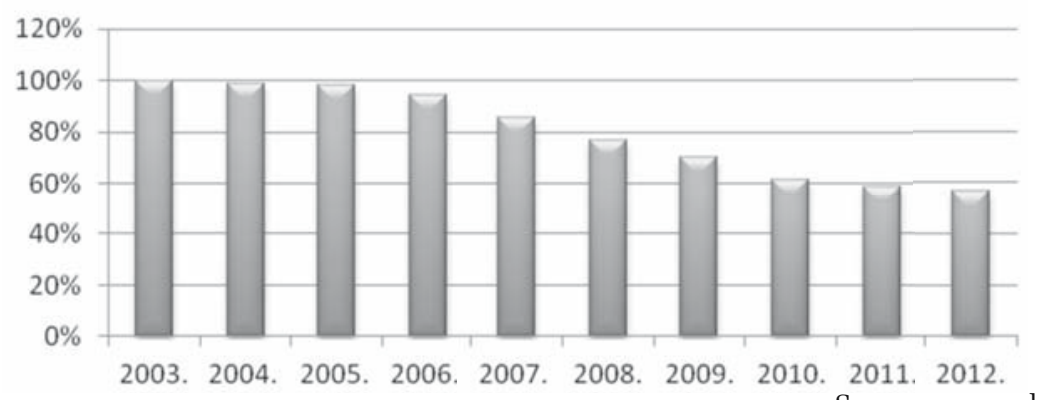

Source: own calculations

Figure 2. Changes in real values of normative per capita basic contribution, 2003-2012

As shown in Figure 1, the nominal values of normative contribution indicate that the level of support increased at first, then it decreased, and in the last few years there was a stagnation. However, we can clearly see in Figure 2 that the real values of government support have been on a steady decline.

Additional normative per-capita grants are small compared to the normative basic contributions, but it is important to look at them to see the full picture. These grants are primarily given for specific purposes, and can only be used accordingly.

Table 3. Additional normative per capita grants 2003-2012

\begin{tabular}{lllllllllll}
\hline $\begin{array}{l}\text { Areas of } \\
\text { entitlement }\end{array}$ & $\mathbf{2 0 0 3}$ & $\mathbf{2 0 0 4}$ & $\mathbf{2 0 0 5}$ & $\mathbf{2 0 0 6}$ & $\mathbf{2 0 0 7}$ & $\mathbf{2 0 0 8}$ & $\mathbf{2 0 0 9}$ & $\mathbf{2 0 1 0}$ & $\mathbf{2 0 1 1}$ & $\mathbf{2 0 1 2}$ \\
\hline $\begin{array}{l}\text { Pedagogical } \\
\text { professional } \\
\text { examination }\end{array}$ & 14,500 & 15,000 & 15,000 & 11,700 & 11,700 & 11,700 & 11,700 & megsz. & 6,300 & 6,300 \\
\hline $\begin{array}{l}\text { Teacher } \\
\text { textbooks* }\end{array}$ & 14,000 & 14,000 & megsz. megsz. megsz. megsz. megsz. megsz. megsz. megsz. \\
\hline
\end{tabular}




\begin{tabular}{lcccccccccc}
\hline $\begin{array}{l}\text { Areas of } \\
\text { entitlement }\end{array}$ & $\mathbf{2 0 0 3}$ & $\mathbf{2 0 0 4}$ & $\mathbf{2 0 0 5}$ & $\mathbf{2 0 0 6}$ & $\mathbf{2 0 0 7}$ & $\mathbf{2 0 0 8}$ & $\mathbf{2 0 0 9}$ & $\mathbf{2 0 1 0}$ & $\mathbf{2 0 1 1}$ & $\mathbf{2 0 1 2}$ \\
\hline $\begin{array}{l}\text { Student } \\
\text { textbooks }\end{array}$ & 2,400 & 2,400 & 2,400 & 1,000 & 1,000 & 1,000 & 1,000 & 1,000 & 1,000 & 1,000 \\
\hline $\begin{array}{l}\text { Free } \\
\text { textbooks }\end{array}$ & 5,600 & 9,600 & 9,600 & 10,000 & 10,000 & 10,000 & 10,000 & 10,000 & 10,000 & 10,000 \\
\hline $\begin{array}{l}\text { Student } \\
\text { sports }\end{array}$ & 1,200 & 1,300 & 1,300 & 430 & 430 & 430 & 430 & megsz. megsz. megsz. \\
$\begin{array}{l}\text { Professional } \\
\text { development }\end{array}$ & 2,617 & 2,200 & 2,600 & 2,600 & 2600 & megsz. megsz. megsz. & 1,750 & 1,750 \\
\hline $\begin{array}{l}\text { Pedagogical } \\
\text { professional } \\
\text { services }\end{array}$ & 720 & 720 & 720 & 720 & 720 & megsz. megsz. megsz. & 0 & 0 \\
$\begin{array}{l}\text { Professional } \\
\text { examination }\end{array}$ & 6,000 & 10,000 & 9,700 & 7,000 & 12,000 & 10,000 & 8,000 & 6000 & 8,000 & 8,000 \\
\hline $\begin{array}{l}\text { Cultural } \\
\text { and leisure } \\
\text { activities }\end{array}$ & 1,000 & 1,000 & 1,000 & megsz. megsz. megsz. megsz. megsz. megsz. megsz. \\
\hline
\end{tabular}

Source: National Budget Act of Hungary, 2003-2012

$60 \%$ of the types of support listed above are no longer available in 2010. This means the school proprietors had to find their own resources to fund these projects. Government support was also on the decline or remained at the same level in all the other areas, so proprietors needed to dedicate more of their own resources for those as well. In 2011, a few areas where government funding had been stopped earlier were supported again. For form-master bonuses, for example, schools received 26,000 HUF/capita/year. This was a very small amount compared to a school's budget, but schools were happy to receive any small amount as they were struggling more and more financially.

\section{Additional Normative Per-Capita Grant for Church Schools}

It is important to look at this type of grant because it is the same amount local governments had to add to the funding from the central budget in order to operate their schools. Adding up the funds school proprietors received from the central budget with the additional grant for church schools, we get the amount necessary for the operation of the schools. In the following table, we can see the changes in government funding (normative per-capita basic contribution) and funding by the proprietor (additional normative per-capita grant for church schools) from 2003 to 2012. 
Table 4. Government and proprietor support for schools 2003-2012 (thousand HUF)

\begin{tabular}{ccccc}
\hline & Basic contr. & $\begin{array}{c}\text { Additional } \\
\text { contr. for church } \\
\text { schools. }\end{array}$ & Total & Additional/Basic. \\
\hline 2003 & 109,56 & 59,442 & 169002 & $54.26 \%$ \\
\hline 2004 & 113,52 & 64,237 & 177,757 & $56.59 \%$ \\
\hline 2005 & 120 & 61,44 & 181,44 & $51.20 \%$ \\
\hline 2006 & 120 & 61,906 & 181,906 & $51.59 \%$ \\
\hline 2007 & 112,487 & 91,2 & 203,687 & $81.08 \%$ \\
\hline 2008 & 109,252 & 104,16 & 213,412 & $95.34 \%$ \\
\hline 2009 & 105,662 & 117,936 & 223,598 & $111.62 \%$ \\
\hline 2010 & 96,442 & $91,200^{*}$ & 187,642 & $94.56 \%$ \\
\hline 2011 & 96,442 & $110,400^{*}$ & 206,842 & $114.47 \%$ \\
\hline 2012 & 96,442 & $110,400^{*}$ & 206,842 & $114.47 \%$ \\
\hline
\end{tabular}

( ${ }^{*}$ additional contribution is received as an advance payment)

Source: own calculations

It can be clearly seen that while in 2003 proprietors needed to add 54 HUF to every 100 HUF of government support, by 2012, this amount increased to almost 114 HUF. Figure 3 makes it even more visible.

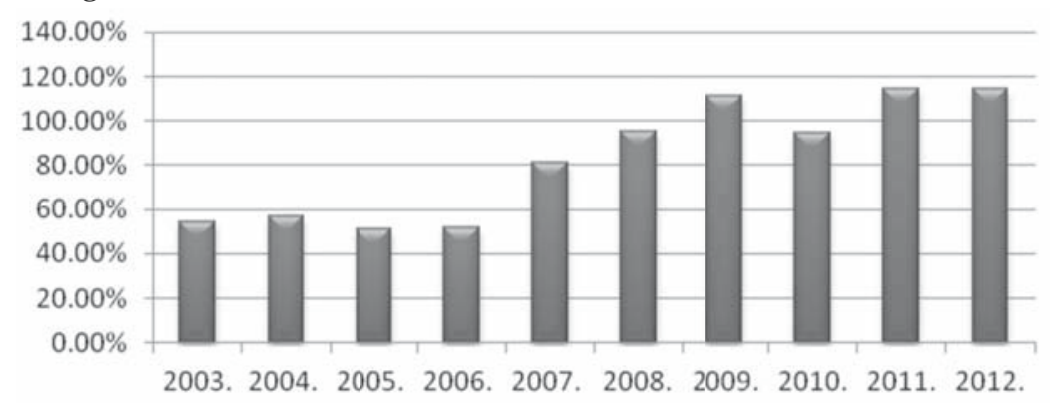

Source: own calculations

Figure 3. Additional per-capita grant for church schools (local governments' own contribution) as a percentage of the normative per-capita basic contribution

It is interesting to note that in 2010 the government not only decreased the basic contribution, but also cut back the advance payment of the additional church school contribution. This has been beneficial for the central budget in the economic crisis, but made the financial situation of church schools quite difficult. As a result, schools had to add more than 120 HUF instead of 95 HUF to every $100 \mathrm{HUF}$ of government support. Because of the financial challenges, local governments tend to give their schools over to the churches, so that they no 
longer have to support them financially - because then the schools would get the additional normative church school contribution from the central budget. The government increased the additional per-capita grant for church schools in 2011, but it was still less than in 2009.

From January $1^{\text {st }} 2013$, the government takes over the operation and also the funding of public schools from the local governments. An advantage of this can be the even distribution of funds between all schools in Hungary. Schools in poorer areas will not have to be affected by the financial struggles of their local government.

\section{Total Financing of the Model School}

Total financing in this case means the sum of the basic contribution and the additional per-capita grant for church schools. There are other grants that can be applied for, for specific purposes or the education of disadvantaged students, but these represent an insignificant amount compared to the main two types of government support.

Table 4 shows the amount of total funding received by the school, although the amounts used are nominal values. Taking the level of inflation into account, we get the real values.

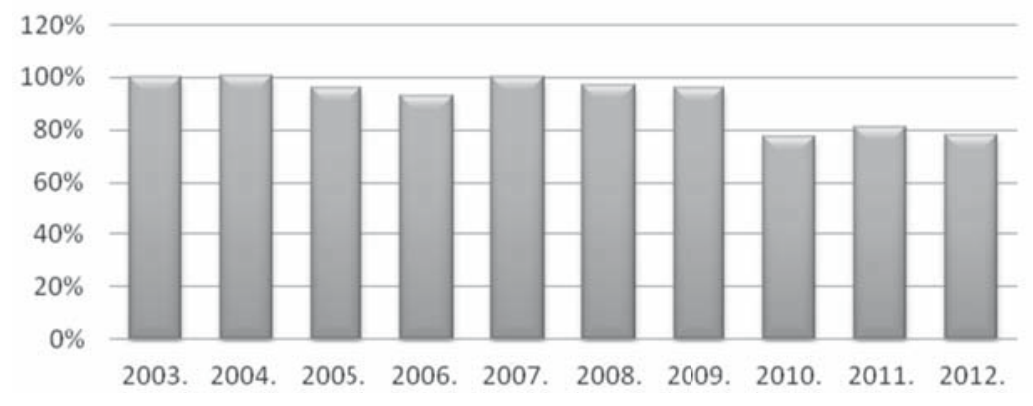

Source: own calculations

Figure 4. Real values of total funding of the model school 2003-2012

Figure 4 reveals that the total funding of the schools remained at the same level up to the year of the economic crisis. However, the previous charts show that from the year 2007, support from the central budget has decreased, forcing local governments to add more resources of their own.

Due to the economic crisis in 2010, the level of total funding decreased. Support from the central budget dropped again, but also the local governments had less funds to make up for the loss. After the new government had come to power, funding increased to some extent, but it remained the same in 2012 as in 2011 - which means a decrease in real values. 
The biggest problem of this financing method is that it is based on enrolment only. For this reason, schools try to maintain their enrolment numbers even if it means giving up on quality. Economically, it is better to have larger classes, even though smaller classes can be taught more efficiently. In this system, expelling students for unacceptable behaviour also leads to money loss.

In the case of vocational training, this system of funding does not take into consideration the expenses of practical training or the sizes of groups. No wonder, vocational training schools have turned away from the demands of the labour market towards courses requiring cheaper practical training. The main issue is that vocations most demanded by the labour market require an expensive training. Schools and their proprietors are no longer able to fund these, especially now that vocational training contributions have been revoked, leaving schools without the extra funds that could be dedicated to refurbish or replace worn equipment. Moreover, students also tend to navigate away from skilled physical labour and look for trainings in office work, IT or economics, creating an excess supply of workforce in these areas. Thus, we can conclude that with the current system of financing, educational goals are taken into consideration to a small extent only.

It is worthwhile to compare the trends of financing education appearing in the statistical yearbooks with the trends showing in our own calculations regarding the model school.

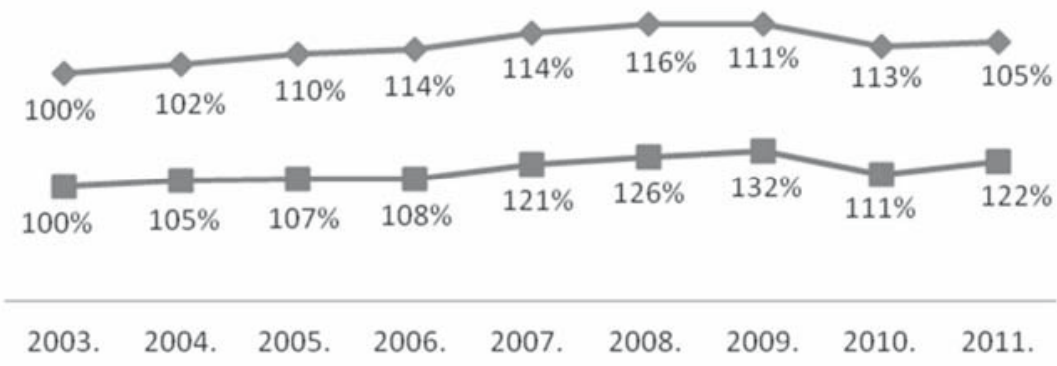

Source: Statistical yearbook 2011/12 and own calculations

Figure 5. Trends of total public education funding (square) and trends of funding for the model school (rhombus) at current values, 2003-2011

In Figure 5, the trends of total education funding (found in statistical yearbooks) are shown using a blue line and our own calculations are shown using a red line.

Compared to the funding of public education as a whole, the direct financing of schools follows a similar trend. Therefore, direct contributions to schools have been on the increase year by year, compared to other types of support. However, with the economic crisis in 2010, direct funds have been cut back in particular. After the change in government, public education costs have decreased, but direct school funding has increased. 


\section{The New System of Public Education Funding Established Due to the New "Teacher Career Model"}

After the elections in 2010, a new approach to education has been adopted. It includes the view that schools not only have to teach students, but also take part in their character formation at a higher level. The previous system of education was not suitable to fulfil this purpose, so the new government began to reform education. Nurturing the gifted and talented became high priority, but assisting struggling students and integrated education also did not lose significance. The system of vocational education is being reorganized dramatically, following the German and Dutch examples.

In 2013, the whole public education was reorganized. Public schools have been taken over from the local governments under the proprietorship of the stateled Klebersberg Institution Maintenance Centre. From September 1, the new "teacher career model" has been introduced; from October 1, the new, teacherbased system of education funding has been established. The reorganization has fundamentally changed the method and scope of education financing.

The new system, like the previous one, also has two main types of contributions. We can measure the changes in the amount of normative support looking at the level of financing received by state-recognized churches. In the schools maintained by the Klebersberg Centre, teachers as well as employees serving education directly receive their full salaries from the state. Other support staff and operation costs are funded by the state and local governments together. There are no exact calculations available yet on the scope of the latter. However, schools maintained by recognized churches are to receive the same amount of support as state-owned schools. Consequently, we are going to work with the amounts allotted to church schools by the Central Budget Act.

\section{Average Salary-Based Support}

Based on enrolment, the National Budget Act determines the number of teachers for each school type, and the average yearly salary of a teacher. The amount calculated based on these numbers gives the average salary-based funding.

In our model school, an elementary school gets the following funds:

- enrolment: 240 pupils

- average teacher number: 11.8 - this means the state budget pays for one teacher after every 11.8 students

- an elementary school teacher's average yearly salary, including affixes is 4,125,200 HUF 
From these data, we can calculate that the elementary school gets 83,904,407 HUF funding from the government for a year to cover the salary of teachers and staff directly assisting education.

Similarly to the elementary school, the law determines the average number of teachers and the average teacher salary for every school type. Based on this data, we can calculate the average salary-based funding of our model school:

Table 5. Salary-based funding of the model school for all school types

\begin{tabular}{lccccc}
\hline School type & Enrolment & $\begin{array}{c}\text { Average } \\
\text { teacher nr. }\end{array}$ & $\begin{array}{c}\text { Nr. of } \\
\text { teachers }\end{array}$ & $\begin{array}{c}\text { Average } \\
\text { teacher salary }\end{array}$ & Funding \\
\hline Elementary (1-8) & 240 & 11.8 & 20.34 & $4,125,300$ & $83,904,407$ \\
\hline High school & 60 & 12.5 & 4.80 & $4,252,200$ & $20,410,560$ \\
\hline $\begin{array}{l}\text { Vocational } \\
\text { secondary }\end{array}$ & 60 & 11.1 & 5.41 & $4,252,200$ & $22,984,865$ \\
\hline $\begin{array}{l}\text { Vocational training } \\
\text { school }\end{array}$ & 120 & 14.7 & 8.16 & $4,252,200$ & $34,711,837$ \\
\hline Total: & & & & & $\mathbf{1 6 2 , 0 1 1 , 6 6 8}$ \\
\hline
\end{tabular}

Source: own calculations

The whole model school gets a total of 162,011,668 HUF average salary-based funding. This type of support also has to cover the $30-35 \%$ raise in teacher salaries.

\section{Operating Costs Support and One-Time Additional Funding for Church Schools}

From October 1, 2013, the additional contribution for church schools has been replaced by a support for operating costs - which can be received by recognized churches and also school-operating foundations that have signed a public education contract with the government.

Currently, this amount is $160,000 \mathrm{HUF} /$ student/year. In the case of our model school, this type of support would be a total of 76,800,000 HUF/year.

Church proprietors receive an additional type of support from the central budget to make up for the costs of the increase in teacher salaries. This amount is $24,300 \mathrm{HUF} /$ student/year. This adds a further 11,664,000 HUF/year to the budget of our model school.

The school gets a total of $\mathbf{8 8 , 6 4 6 , 0 0 0 ~ H U F / y e a r ~ t o ~ c o v e r ~ o p e r a t i n g ~ c o s t s ~ a n d ~ t h e ~}$ salaries of support staff. 


\section{Comparison of the Average Salary-Based Funding with the Normative Funding in 2012}

Table 6. Comparison of the normative funding (2012) and the average salarybased funding (2013)

\begin{tabular}{ccc}
\hline & \multicolumn{2}{c}{ (thousand HUF) } \\
\hline $\begin{array}{l}\text { Basic contribution/average salary } \\
\text { funding }\end{array}$ & $\mathbf{2 0 1 2}$ (old system) & $\mathbf{2 0 1 3}$ (new system) \\
\hline $\begin{array}{l}\text { Additional cost for church schools/ } \\
\text { operation cost support }\end{array}$ & 96,442 & 162,011 \\
\hline \multicolumn{1}{c}{ Total: } & 110,400 & 88,646 \\
\hline & $\mathbf{2 0 6 , 8 4 2}$ & $\mathbf{2 5 0 , 4 7 5}$ \\
\hline
\end{tabular}

The new system of financing provides a yearly funding of 43,633,000 HUF more than the old system. This, however, also has to cover the raise in teacher salaries due to the new "teacher career model". According to statistical yearbooks on public education, schools have to designate almost $70 \%$ of their budget to teacher salaries. A $30 \%$ raise in salaries amounts to 43,436,000 HUF from the total funding in 2012. This means that on average the government has increased the funds designated to schools with the amount needed to cover the raise in teacher salaries.

\section{Conclusion}

Education is a strategic area everywhere in the world because the training of the next generation is a key factor of the labour market, among others. In Hungary, between 2003 and 2012, the financing of education was based on enrolment numbers. Schools received a normative basic per-capita contribution from the central budget based on their enrolment, which was complemented by the local governments operating the schools. From the central budget, church proprietors received the average of the support local governments provided to their schools as an additional per-capita contribution for church schools. The sum of these two types of contributions provided the direct funding of the schools. The amount of the support changed according to the economic situation of the country, which determined how much the central budget was able to dedicate to public education. When the country faced an economic downturn, public education was the first to suffer from the cutting back of funds. With time, local governments provided more and more funding for the schools. In the middle of the first millennial decade, local governments took a lot of loans, and found it increasingly difficult to pay them back. As a result, the central budget had to assist them in supplementing 
the funding of their schools. This has led to the conclusion that if the government has to take over funding why not take over proprietorship as well. From January 1,2013 , the government has taken over the proprietorship of public schools from the local governments, but the new, average salary-based financing came into effect only as of October 1.

Both the macroeconomic calculations and the budget calculations of the model school in our study prove that the new way of financing education has not brought about a dramatic transformation of the system - the change has been only significant with regard to the amounts of funding. Even though the method of calculation is different, the total funding of schools is still eventually determined by the enrolment. This is clearly demonstrated by the comparison of the old and new systems of financing, where we can only see a difference in the amount that funds the raise in teacher salaries, but all other areas are supported to the same extent as earlier. This is particularly true if we assume that teachers consider the raise to be a compensation for the lack of appropriate waging in previous years, and we take into account inflation, the elimination of various bonuses and overtime compensations, and the effect of the increase in the number of classes required to be taught.

Raising teacher salaries by almost one-third is beyond doubt a measure that will increase the prestige of the profession and thus will contribute to a higher quality of education, but we cannot expect it to bring about a breakthrough in public education. We expect the scale of funding to remain similar as in the previous years although the method of calculation has changed. The upcoming years may answer the question whether the financing of public education will be in fact reformed, or the new system introduced from October 1, 2013 will remain only a change in the calculation method.

\section{References}

Harbison, F.; Myers, C. A. (1966). Elméletek az emberi erőforrás fejlődéséről, In: Illés Lajosné (ed.), Az oktatás gazdaságossága (Concepts of human resource development, in: The profitability of education; textbook). Tankönyvkiadó. 21-22.

Malthaus, T. R. (1902). Tanulmány a népesedés törvényéről (An essay on the principle of population). MTA Nemzetgazdasági Bizottsága. 514-518.

Schultz, T. W. (1983). Beruházások az emberi tőkébe (Investment in human capital). KJK 47-49.

Smith, A. (1992). A nemzetek gazdagsága (The wealth of nations). KJK. 110, 282.

Stiglitz, J. E. (2000). A kormányzati szektor gazdaságtana (Economics of the public sector). KJK: Kerszöv. 380-390. 
Polónyi, I. (2002). Az oktatás gazdaságtana (The economics of education). Osiris.

Varga, J. (1998). Oktatás-gazdaságtan (Education economics). Közgazdasági Szemle Alapítvány, Budapest.

Statisztikai Tájékoztató Oktatási Évkönyv 2010/2011 (2011). (The Statistical

Yearbook of Education). Nemzeti Erőforrás Minisztérium, 169-170.

1868. évi XXXVIII. törvénycikk a népiskolai közoktatás tárgyában (Act Nr. XXXVIII on Public School Education, 1868).

1999. évi LXX. törvény a Magyar Köztársaság és az Apostoli Szentszék között a Katolikus Egyház magyarországi közszolgálati és hitéleti tevékenységének finanszírozásáról, valamint néhány vagyoni természetú kérdésről 1997. június 20-án, Vatikánvárosban aláírt Megállapodás kihirdetéséről (Act Nr. LXX/1999 on the agreement between the Republic of Hungary and the Holy See on the financing of the education and public service activities of the Hungarian Catholic Church, and some issues on church property on July 20, 1997). 2002. évi LXII. Törvény a Magyar Köztársaság 2003. évi költségvetéséről (1, 3,

5, 8. számú melléklet) (Act Nr. LXII/2002 on the national budget for the year 2003, appendices 1, 3, 5 and 8).

2003. évi CXVI. Törvény a Magyar Köztársaság 2004. évi költségvetéséról és az államháztartás hároméves kereteiről (1, 3, 5, 8. számú melléklet) (Act Nr. CXVI/2003 on the national budget for the year 2004 and the 3-year frameworks of public finance, appendices 1, 3, 5 and 8).

2004. évi CXXXV. Törvény a Magyar Köztársaság 2005. évi költségvetéséről (1,

3, 5, 8. számú melléklet) (Act Nr. CXXXV/2004 on the national budget for the year 2005, appendices 1, 3, 5 and 8).

2005. évi CLIII. Törvény a Magyar Köztársaság 2006. évi költségvetéséról (1, 3,

5, 8. számú melléklet) (Act Nr. CLIII/2005 on the national budget for the year 2006, appendices 1, 3, 5 and 8).

2006. évi CXXVII. Törvény a Magyar Köztársaság 2007. évi költségvetéséről (1,

3, 5, 8. számú melléklet) (Act Nr. CXXVII/2006 on the national budget for the year 2007, appendices 1, 3, 5 and 8).

2007. évi CLXIX. Törvény a Magyar Köztársaság 2008. évi költségvetéséről (1, 3,

5, 8. számú melléklet) (Act Nr. CLXIX/2007 on the national budget for the year 2008, appendices 1, 3, 5 and 8).

2008. évi CII. Törvény a Magyar Köztársaság 2009. évi költségvetéséről (1, 3, 5, 8. számú melléklet) (Act Nr. CII/2008 on the national budget for the year 2009, appendices 1, 3, 5 and 8).

2009. évi CXXX. Törvény a Magyar Köztársaság 2010. évi költségvetéséről (1, 3, 5, 8. számú melléklet) (Act Nr. CXXX/2009 on the national budget for the year 2010, appendices 1, 3, 5 and 8). 
2010. évi CLXIX. Törvény a Magyar Köztársaság 2011. évi költségvetéséről (1, 3, 5, 8. számú melléklet) (Act Nr. CLXIX/2010 on the national budget for the year 2011, appendices 1, 3, 5 and 8).

2011. évi CLXXXVIII. Törvény a Magyarország 2012. évi központi költségvetéséről (1, 3, 5, 8. számú melléklet) (Act Nr. CLXXXVIII/2011 on the national budget for the year 2012, appendices 1, 3, 5 and 8).

2011. évi CLXXXVII. törvény a szakképzésről (Act Nr. CLXXXVII/2011 on vocational training).

2011. évi CXC. törvény a nemzeti köznevelésről (Act Nr. CXC/2011 on national public education).

2012. évi CCIV. törvény Magyarország 2013. évi központi költségvetéséről (Act Nr. CCIV/2012 on the national budget of Hungary for the year 2013).

2013. évi CXXIX. törvény az oktatás szabályozására vonatkozó egyes törvények módosításáról (Act Nr. CXXIX/2013 on the modification of some education laws).

2013. évi CXLIV. törvény Magyarország 2013. évi központi költségvetésének módosításáról (Act Nr. CXLIV/2013 on the modification of the central budget of Hungary for the year 2013). 